\title{
16. DIATOM BIOSTRATIGRAPHY OF SITES 434, 435, AND 436, NORTHWESTERN PACIFIC, LEG 56, DEEP SEA DRILLING PROJECT
}

\author{
Howard E. Harper, Jr., Atlantic Richfield Company, Dallas, Texas
}

\section{INTRODUCTION}

We drilled and recovered sediment from three sites during Leg 56: (1) Site 434: Holes 434, 434A, and 434B; $39^{\circ} 44.8^{\prime} \mathrm{N}, 144^{\circ} 06.1^{\prime} \mathrm{E}$. (2) Site 435: Holes 435, $435 \mathrm{~A}$; $39^{\circ} 44.09^{\prime} \mathrm{N}, 143^{\circ} 47.53^{\prime} \mathrm{E}$. (3) Site 436: Hole 436; $39^{\circ}$ $55.96^{\prime} \mathrm{N}, 145^{\circ} 33.47^{\prime} \mathrm{E}$. These sites are part of a transect across the Japan Trench from the oceanic plate (Site 436) and up the landward trench slope (Sites 434 and 435). Leg 57 sites continue the transect line from the slope onto the shelf.

All holes on Leg 56 recovered diatomaceous sediments. I found common to abundant and well-preserved diatoms from the highest to the lowest sample at Site 435. Diatoms are common and preservation is good in the upper parts at Site 434 and 436 but becomes worse in the lower parts; samples below Core $38(359 \mathrm{~m})$ in Hole 436 are barren.

The diatoms from the samples I examined are very similar to those reported by Koizumi $(1973,1975 a)$ from DSDP Legs 19 and 32 . The samples contain zonal marker species of both the Northwestern Pacific diatom zonation of Koizumi (1977) and the tropical Pacific diatom zonation of Burckle (1972), although the tropical taxa are usually less abundant than the northern taxa.

I used Koizumi's zonation and datum levels (1975a; 1977, Figure 1) for the middle Miocene through Pleistocene sections at Site 436 and for the lower Pliocene through Pleistocene sections at Site 435. At Site 434, however, part of the sequence of datum levels does not follow the normal pattern published by Koizumi. There are alternating assemblages which usually identify the Denticula seminae fossilis- $D$. kamtschatica Concurrent Range Zone and the D. kamtschatica Partial Range Zone. Koizumi and others (Burckle and Opdyke, 1977) have found these zonal assemblages to be nonrepetitive in many sections in the North Pacific. A detailed discussion of the possible causes of what I note in Hole 434 is in the Site 434 chapter.

Because of time restrictions and the large number of samples, some samples were examined in greater detail than others. I concentrated on Hole 434 because of its repetitious zonal assemblages and on Hole 436 because of its age continuity. Table 1 lists the diatom taxa used in this report.

\section{PREPARATION AND EXAMINATION}

On board the Challenger I processed samples, mainly core catcher samples, by making a smear slide of waterdiluted soft sediment and mounting the cover slip with
Hyrax. Harder samples were boiled in a 30 per cent hydrogen peroxide solution until disaggregated and mounted like the preceding. Samples processed on shore were also boiled in 30 per cent hydrogen peroxide, then centrifuged to remove finer materials and mounted with Naphrax. I examined the slides in one of two ways: 1) Scanning at least half of the slide and noting the presence or absence of established marker taxa. I did this at 300 to 500 magnification, using higher magnification when needed for taxa identification. 2) Tabulation of the first 300 specimens, noting their numerical abundance, then continuing, noting presence or absence of additional taxa, until 1000 to 3000 specimens had been examined. If I found more than 15 specimens of a taxon during the first 300 specimens, I considered it abundant. I excluded Thalassionema, Thalassiothrix, Chaetoceros, and fresh-water taxa.

In addition, while scanning several samples from Hole 434 according to 1), I tabulated the number of specimens of Denticula kamtschatica and D. seminae fossilis to obtain their ratio.

\section{DIATOM ZONATION}

Published studies from 1970 to 1978 have added greatly to our knowledge of the diatom biostratigraphy of the Pacific. Burckle (1972), Burckle and Opdyke (1977), Koizumi (1977), and Harper (1977) have correlated many diatom datum levels to paleomagnetic stratigraphy and radiometric chronology. These zonations, datum levels, and age correlations are shown in Figure 1. Burckle's (1972) eastern equatorial Pacific marker taxa and Koizumi's (1977) Northwestern Pacific marker taxa have been found together in samples or parts of sections across the mid-latitudes of the Pacific. Such occurrences are reported by Koizumi (1975a), Burckle and Opdyke (1977), Barron et al. (1978), and Harper (1978). Harper (1978) has also shown that the first appearance of Denticula kamtschatica is older in the Northwest Pacific than in California coastal area. Diatom biostratigraphy of sections near the geographic limits of the northern and equatorial provinces must be done carefully. Neither the paleomagnetic nor the radiometric assignments of datum levels always apply strictly in such areas; rather, they represent age limits, because the taxon may have existed at the edge of its geographic distribution for only part of its total time range.

\section{Site $\mathbf{4 3 4}$}

We drilled at this site on the landward accretionary wedge of the Japan Trench. We recovered only 18 to 19 


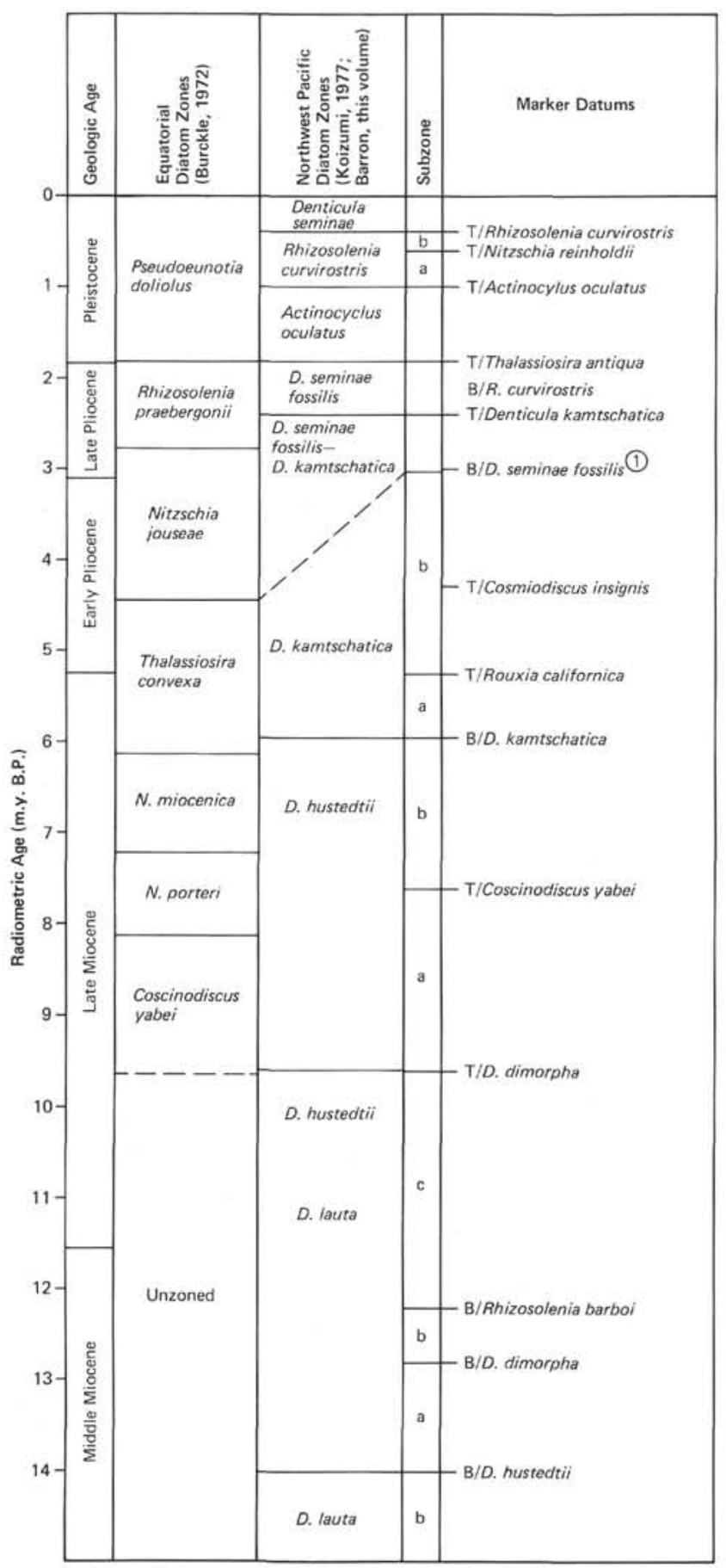

Figure 1. Pacific diatom zones. (1) D. seminae fossilis has a diachronous first appearance, being older [4.2 m.y.] in the north and younger [ 3.2 m.y.] in the mid-latitudes.)

per cent of the 637.5-meter cored interval. Figure 2 shows the datum levels and zonal assignments. Core 434-1 contains a late Pleistocene diatom assemblage correlated to the Denticula seminae Zone. Core 434-2, however, is late Pliocene in age, assignable to the Denticula seminae fossilis Zone. The Rhizosolenia curvirostris and Actinocyclus oculatus zones are missing,
TABLE 1

Taxa Used in This Chapter

\begin{tabular}{|c|c|}
\hline Actinocyclus ingens Rattray & Hemidiscus cuneiformis Wall \\
\hline A. ochotensis Jousd & Kisseleviella carina Sheshukova-Poretzkaya \\
\hline A. oculatus Jousé & Macrora stella (Azpeitia) Hanna \\
\hline A. tsugarensis Kanaya & Mediaria splendida Sheshukova-Poretzkaya \\
\hline Annellus californicus Tempère & Nitzschia fossilis (Frenquelli) Kanaya \\
\hline Asterolampra acu tiloba Forti & N. jouseae Burckle \\
\hline Cosmiodiscus insignis Jousé & N. miocenica Burckle \\
\hline Coscinodiscus endoi Kanaya & N. praereinholdii Schrader \\
\hline C. lewisianus Greville & $N$. reinholdii Kanaya \\
\hline C. Marginatus Ehrenberg & Pseudoeunotia doliolus (Wall.) Grunow \\
\hline C. plicatus Grunow & Rhizosolenia barboi Brun \\
\hline C. pustulatus Mann & R. curvirostris Jousé \\
\hline C. symbolophorus Grunow & R. miocenica Schrader \\
\hline C. temperei Brun & R. praebergonii Muchina \\
\hline C. yabei Kanaya & Rouxia californica Peragallo \\
\hline Craspedodiscus coscinodiscus Ehrenberg & Stephanopyxis horridus Koizumi \\
\hline Cussia paleacea (Grunow) Schrader & Synedra jouseana Sheshukova-Poretzkaya \\
\hline C. tatsunokuchiensis (Koizumi) Schrader & Thalassiosira antiqua (Grunow) Cleve-Euler \\
\hline Denticula hustedtii Simonsen and Kanaya & T. burckliana Schrader \\
\hline D. kamtschatica Zabelina & $T$, convexa Muchina \\
\hline D. lauta Bailey & T. miocenica Schrader \\
\hline D. punctata Schrader & T. nidulus (Tempere and Brun) Jousé \\
\hline D. seminae Simonsen and Kanaya & T. oestrupii (Osten,) Proskina-Lavrenko \\
\hline D. seminae fossilis Schrader & T. usatchevii Jousd \\
\hline Goniothecium tenue Brun & T. zabelinae Jousé \\
\hline
\end{tabular}

Note: Taxonomy of these taxa may be found in Koizumi $(1973,1975 \mathrm{a}, 1975 \mathrm{~b})$ and Schrader $(1973,1974 a, 1974 b)$.

indicating a hiatus of about $1.5 \mathrm{~m} . \mathrm{y}$. I found the top occurrence of $D$. kamtschatica in Core 434-4, and the concurrent range of $D$. kamtschatica and $D$. seminae fossilis extends continuously in the samples I examined through 434-6,CC. Below this level and through Sample 434-33-3, $72 \mathrm{~cm}$, I found several repetitions of the typical $D$. seminae fossilis- $D$. kamtschatica and the $D$. kamtschatica zonal taxa. These are shown in Table 2. The definitions of the two zones are based on the concurrent range of $D$. seminae fossilis and $D$. kamtschatica for that zone and the nonconcurrent range of D. kamtschatica, respectively.

Taxa which Koizumi (1975b) associated with the $D$. seminae fossilis- $D$. kamtschatica Zone or younger zones are Rhizosolenia praebergonii and $A$. oculatus. Taxa which he associated with the $D$. kamtschatica Zone or older zones are Cosmiodiscus insignis, Coscinodiscus symbolophorus, C. temperei, Rouxia californica, and Goniothecium tenue. There are two types of data in Table 2 , as discussed earlier. Table 2 shows an assemblage difference between the samples with $D$. seminae fossilis and $D$. kamtschatica and the samples with only D. kamtschatica. A. oculatus and $R$. praebergonii occur only with $D$. seminae fossilis, and Cosmiodiscus insignis and $R$. californica occur with $D$. kamtschatica alone.

Samples 434-28-2, 82cm, and 434-28,CC, although low in diatom abundance and poor preservationally, contain specimens of the late to middle Miocene species $D$. lauta, $A$. ingens, $G$. tenue and $D$. punctata, with $D$. kamtschatica and $D$. seminae fossilis absent. In the next sample down, 434-39,CC, I find $D$. seminae fossilis and D. kamtschatica again. In Hole 434B, from Samples $2, \mathrm{CC}$ to $17, \mathrm{CC}$, I find the $D$. kamtschatica assemblage and place the top of the D. hustedtii Zone at Sample 434B-18,CC, although preservation and diatom abundance become very poor, several samples within Hole 434B being barren $(25, \mathrm{CC} ; 33, \mathrm{CC} ; 34, \mathrm{CC} ; 37, \mathrm{CC})$ and core recovery very bad. The tops of $C$. insignis and $R$. californica are tentatively placed in Core 434B-7 and 


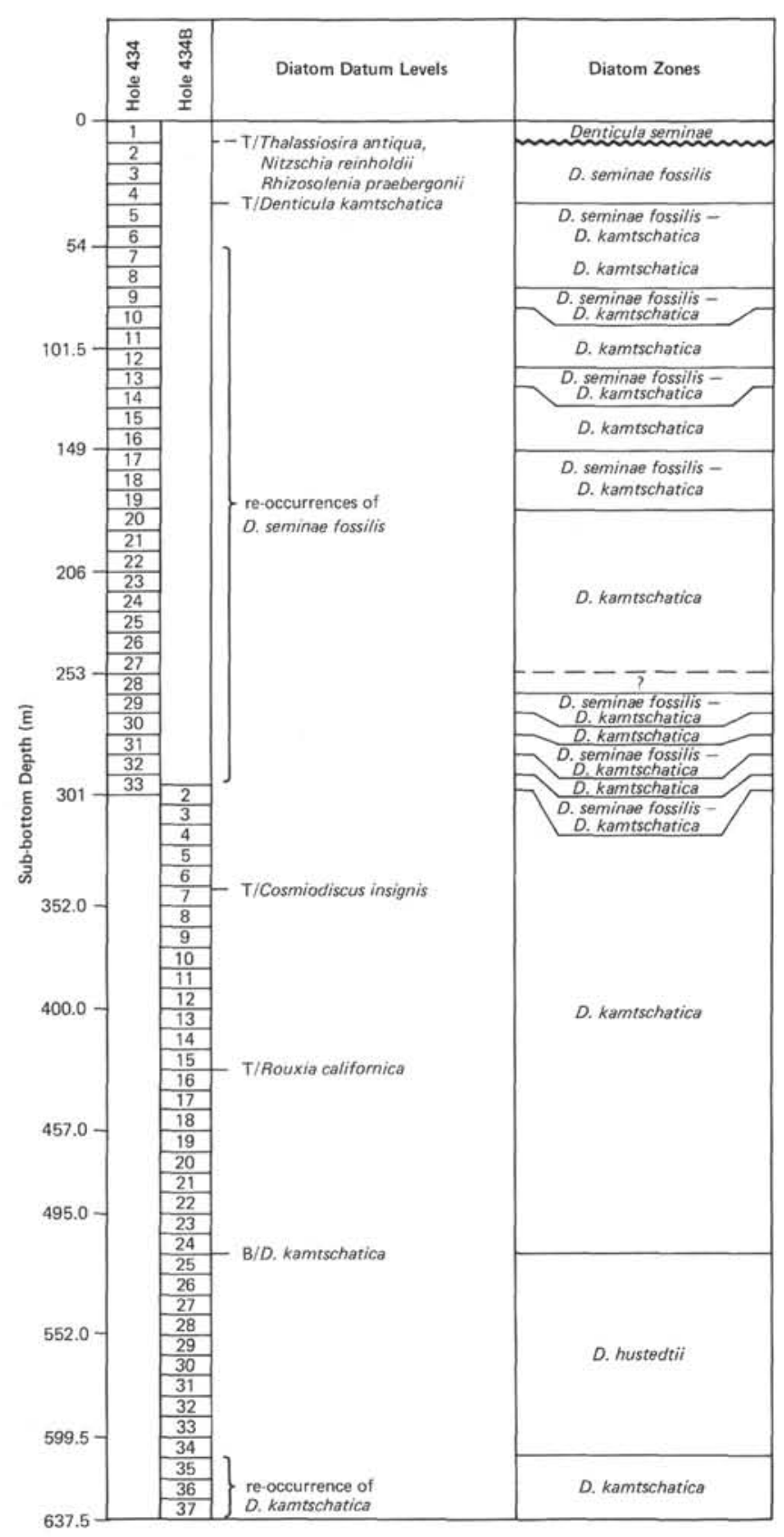

Figure 2. Placement of datum levels at Site 434. $(\mathrm{T} /=$ top occurrence, $\mathrm{B} /=$ base occurrence.)

Core 434B-15, respectively, although both species appear higher in the section within the confused interval of Hole 434.

The abundances of Coscinodiscus marginatus are recorded in Table 2 to show the relation between its abundance and the preservational state of a sample. Samples with only moderate or poor preservation represent most of the $D$. kamtschatica Zone samples, whereas the $D$. seminae fossilis- $D$. kamtschatica Zone generally contains samples with good preservation. Whether this is due to differential diagenesis of the samples because of differing ages or to tectonic forces or differences in the ecological conditions during deposition is not evident.
Probable causes for the repetitions of the diatom zonal assemblages in Hole 434 are limited. The simplest is to explain the occurrences of $D$. seminae fossilis below Sample 434-6,CC as the result of downhole contamination. This conclusion is generally supported by 1) the fact that except for Sample 434-9-1, $70 \mathrm{~cm}$, all assemblage breaks occur at core boundaries; 2 ) the drilling difficulty and poor core recovery of this section; 3 ) the last occurrence of $D$. seminae fossilis is at the basal part of Hole 434, and Hole 434B, which was drilled from the sediment surface to 295.5 meters, does not contain any of the younger assemblages. If this conclusion is correct, the basal appearance of $D$. seminae fossilis is at a sub-bottom depth of about 54.0 meters. The total thickness of the D. seminae fossilis-D. kamtschatica Zone is 20 meters and that of $D$. kamtschatica Zone at about 400 meters.

Another explanation is that repetition of zonal sequence is caused by faulting. Although the general tectonic setting of the area supports this thesis, it is unlikely for so many faults, with as little as $\mathbf{2 0}$ meters between them, to occur.

A third cause for the repetitions is slumping - that is, a downslope movement of essentially $D$. kamtschatica zonal sediments during the regular pelagic deposition of $D$. seminae fossilis zonal taxa. This explanation too is supported by the tectonic setting and by the missing Pleistocene section. If it is correct, the $D$. seminae fossilis- $D$. kamtschatica Zone occurs from about 35 meters to 300 meters sub-bottom and the D. kamtschatica Zone from 300 to 457 meters sub-bottom.

The last probable explanation is climatic fluctuations during the time range of the $D$. seminae fossilis $-D$. kamtschatica Zone. Hole 434 is located near the high and low latitude diatom provincial boundaries and near the convergence of the northern Oyashio and southern Kuroshio currents. Small changes in the circulation patterns could cause major changes in the diatom assemblages deposited in this area. This explanation would produce the same zonal boundaries as the slumping hypothesis.

Unfortunately, other evidence such as sediment character, sedimentary structures, and foraminifer and radiolarian assemblages have not given conclusive support to any of the foregoing hypotheses. For example, the sediment accumulation rates implied by the downhole contamination and those implied by slumping or climate are quite different (Figure 3).

\section{Site $\mathbf{4 3 5}$}

We drilled Holes 435 and 435A on the upper slope of the landward side of the Japan Trench. Figure 4 shows the placement of the diatom datum levels and the zonal assignments. Because I used the shipboard slides for this site, the data are less detailed than for Sites 436 and 434 . The sequence of North Pacific zonal markers is the same as that published by Koizumi. Diatoms are abundant and well preserved in all samples except for Sample 435A-11,CC, the lowest sample, which has only moderate preservation. In examining at least one sample per core, I found no occurrence of Denticula seminae fossilis or its associated species below Sample 435-13,CC. 
TABLE 2

Occurrence of Key Taxa in Lower Part of Hole 434

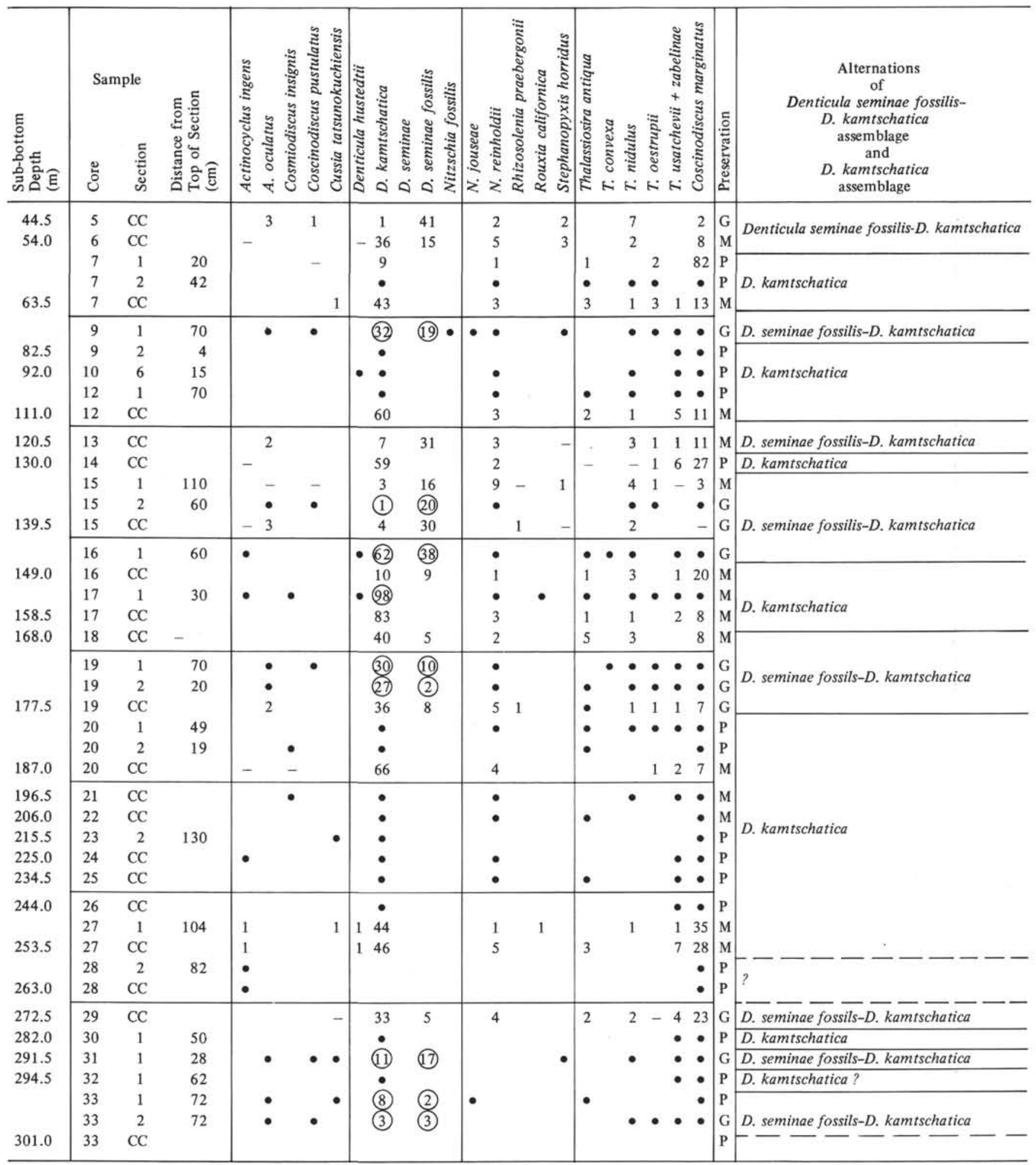

Note: $30=$ per cent relative abundance on counted slide, $(8)=$ number of specimens on scanned slide, $-=\langle 1$ per cent relative abundance on counted slide, $\bullet=$ present on scanned slide. 


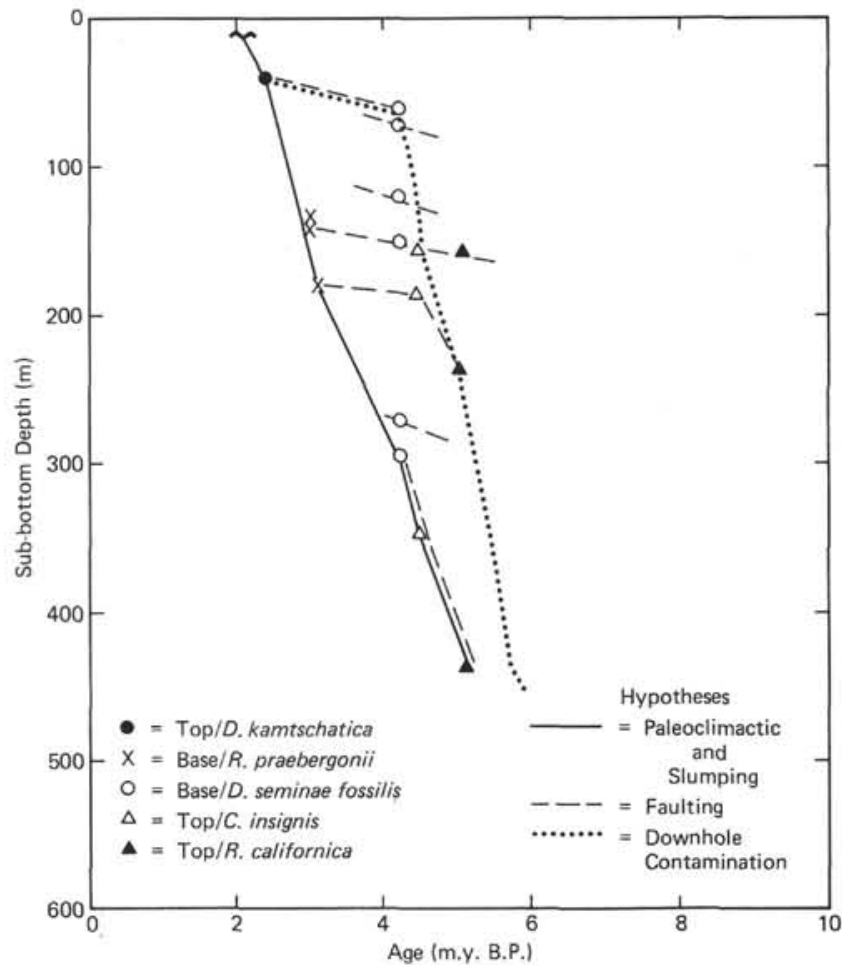

Figure 3. Sediment accumulation rates for Site 434.

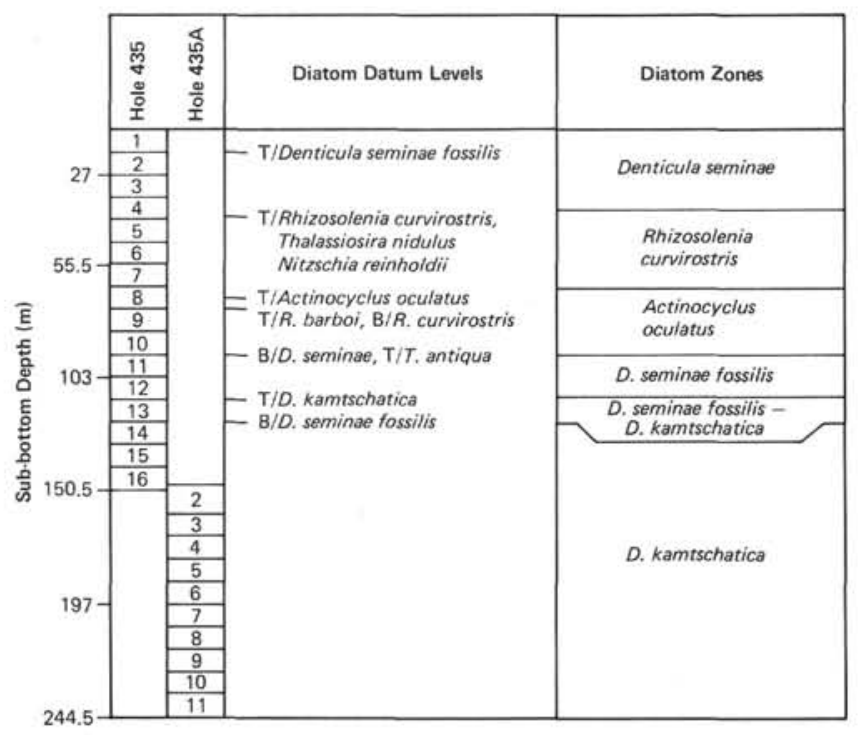

Figure 4. Placement of datum levels at Site 435. $(\mathrm{T} /=$ top occurrence, $\mathrm{B} /=$ base occurrence.)

\section{Site $\mathbf{4 3 6}$}

We drilled and continuously cored about 630 meters of siliceous sediment in Hole 436. Table 3 shows the occurrence of key marker taxa in the hole. Reworked specimens are present in most samples, and, going downhole, I placed more reliance on abrupt increase in abundance and on continuous occurrence in closely spaced samples than on presence or absence. From the top of the Denticula kamtschatica Zone downhole, I placed the zonal boundaries based on these criteria. In the lower part of Core 436-27, the diatom preservation becomes poor and abundance is low. I find the identification of the top of the $D$. hustedtii Zone difficult. Based on the first D. kamtschatica and the first Nitzschia fossilis, I put the top between the Cores 436-28 and 436-29. D. hustedtii, Actinocyclus ingens, and Coscinodiscus endoi all range concurrently from Cores 30 to 35 . Some taxa (Kisseleviella carina, Macrora stella) from the D. hustedtii-D. lauta Zone are sporadically present in this interval, but $D$. lauta does not appear until Core 36 . I recognize a small overlap of the $D$. hustedtii and $D$. lauta in samples from Cores 36 and 37 and place these samples with the $D$. hustedtii-D. lauta Zone. Sample $37-5,50 \mathrm{~cm}$, is probably of middle Miocene age, from near the top of the D. lauta Zone. All samples below this level were barren of useful diatom remains, with only a few badly corroded fragments present.

The large amount of reworking of marker taxa in the 320 to 360 meter sub-bottom interval of Hole 436 is probably due to a decreased sedimentation rate, as reflected in the accumulation rate diagram (Figure 5) and in the change in lithology from a radiolarian-diatom mudstone downhole to a pelagic clay. The lack of diatoms in Hole 436 is not the result of silica diagenesis but of a change in diatom primary productivity.

The early Miocene and Paleogene are represented by only a 20-meter section of stiff, chocolate brown, Mnrich abyssal clay. The hole bottomed in hard chert of Cretaceous age, the same color as the abyssal clays. In conjunction with the lithologic and biostratigraphic data from Sites 303 and 304 of Leg 32, the age of the first Tertiary development of the modern oceanic circulation and productivity pattern of this area of the North Pacific can be deduced. Figure 6 gives the backtraced positions of Sites 303, 304, and 436 based on Lancelot and Larson (1975). This reconstruction places Site 436 about $10^{\circ}$ of latitude to the west of 303 and 304; therefore it should enter the high productivity area about 15 m.y. before either of them. Yet at all three sites the oldest Tertiary biogenic sediments are roughly late middle Miocene. This date must represent the first development of a circulation and productivity pattern equivalent to that of today.

\section{SUMMARY}

Sites 434,435 , and 436 all represent large accumulations of richly diatomaceous sediments. Site 435 , from preliminary examination, has an almost 100-meter-thick continuous record of Pleistocene deposition and presents an excellent opportunity for detailed siliceous biostratigraphy. Site 436 also has an excellent section for detailed late Neogene diatom biostratigraphy. At both of these sites I found the sequence of diatom zonal datums in the same order as previously documented in the literature. Hole 434, however, represents the most interesting of Leg 56 because of the alternation of the assemblages of the $D$. seminae fossilis- $D$. kamtschatica Zone and the D. kamtschatica Zone. Further work on this hole is necessary. 
TABLE 3

Occurrence of Key Diatom Taxa in Hole 436

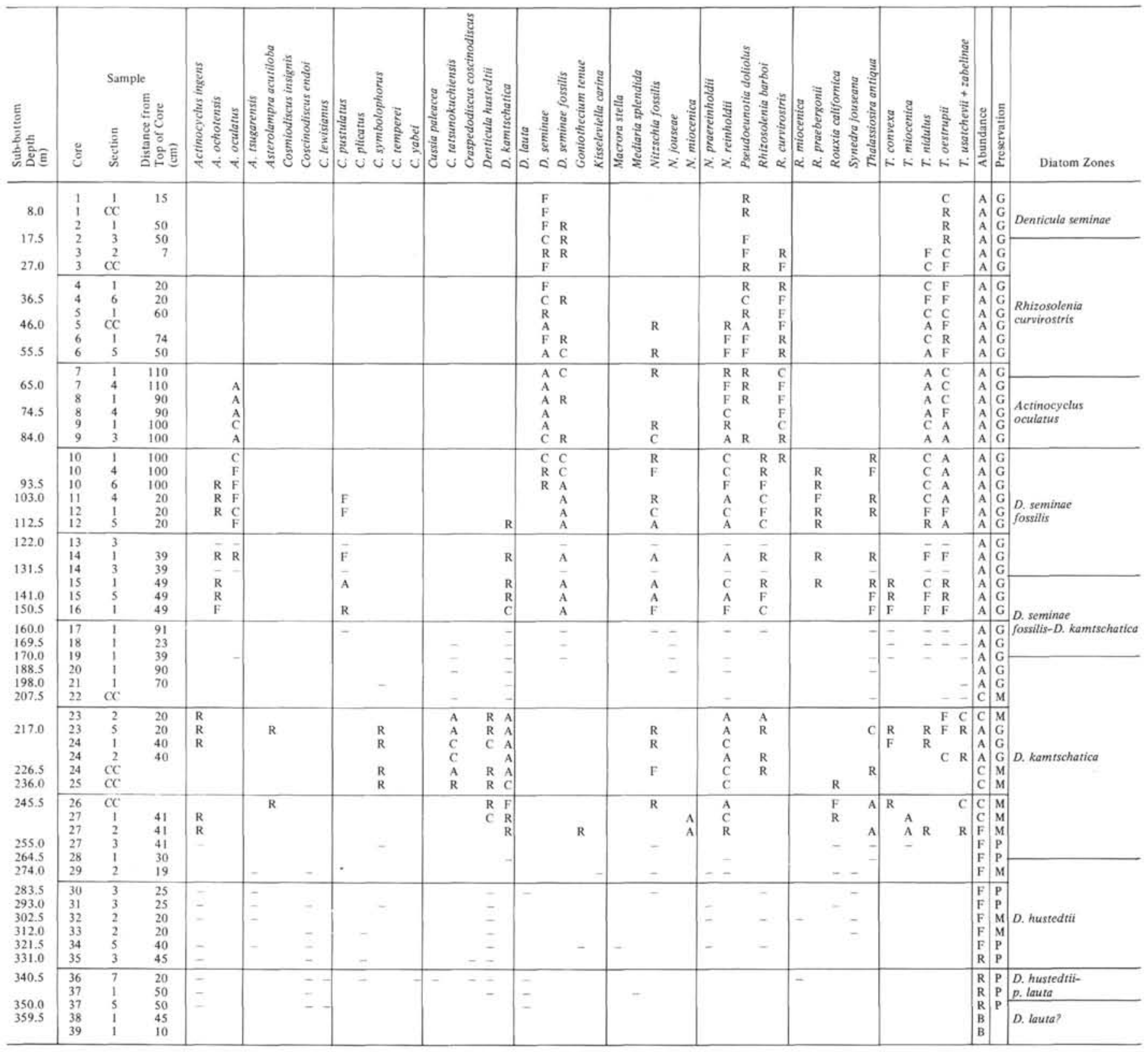

Note: $\mathrm{A}=$ abundant, $\mathrm{F}=$ few $\mathrm{C}=$ common, $\mathrm{R}=$ scarce, $-=$ present, $\mathrm{G}=$ good, $\mathrm{M}=$ moderate, $\mathrm{P}=$ poor.

\section{ACKNOWLEDGMENTS}

I wish to thank the shipboard staff of Leg 56 for making the cruise enjoyable. Discussions with John Barron, Lloyd Burckle, and John Rider have improved this manuscript. I also thank Harald Poelchau and John Rider for reviewing this chapter for publication and Kaye Melton for typing it.

\section{REFERENCES}

Barron, J., 1976. Revised Miocene and Pliocene diatom biostratigraphy of Upper Newport Bay, Newport Beach, California. Mar. Micropaleont., 1, 27-63.

Barron, J., von Huene, R., and Nasu, N., 1978. Correlation of high and low latitude upper Miocene diatom datum levels at D.S.D.P. Site 438 in the Northwest Pacific. Abstr. and Program I.G.C.P., Project 114, Third Working Group Mtg., pp. 5-6. (Abstract)

Burckle, L. H., 1972. Late Cenozoic planktonic diatom zones from the Eastern Equatorial Pacific. Beih. Nova Hedwigia, $39,217-246$.

Burckle, L., and Opdyke, N., 1977. Late Neogene diatom correlations in the circum-Pacific. Proc. First Int. Cong. Pacific Neogene Strat., Tokyo 1976, pp. 255-284.

Harper, H. E., Jr., 1977. Diatom biostratigraphy. In Ujiie, H., et al., Biostratigraphy, paleomagnetism and sedimentology of late Cenozoic sediments in Northwestern Hokkaido, Japan, Bull. Nat. Sci. Mus., 3 (No. 1), 85-90.

1978. Diatom biostratigraphy of the Miocene/Pliocene boundary in the North Pacific. Abstr. and Program I.G.C.P., Project 114, Third Working Group Mtg., p. 15. (Abstract) 
Koizumi, I., 1973. The late Cenozoic diatoms of Sites 183-193, Leg 19, Deep Sea Drilling Project. In Creager, J. S., Scholl, D. W., et al., Init. Repts. DSDP, 19: Washington (U.S. Govt. Printing Office), 805-855. , 1975a. Late Cenozoic diatom biostratigraphy in the circum-Pacific region. J. Geol. Soc. Japan, 81, 611-627. , 1975b. Neogene diatoms from the northwestern Pacific Ocean, Deep Sea Drilling Project. In Larson, R. L., Moberly, R., et al., Init. Repts. DSDP, 32: Washington (U.S. Govt. Printing Office), 865-890. 1977. Diatom biostratigraphy in the North Pacific Region. Proc. First Int. Cong. Pacific Neogene Strat., Tokyo 1976 , pp. $235-253$.

Lancelot, Y., and Larson, R., 1975. Sedimentary and tectonic evolution of the Northwestern Pacific. In Larson, R., Moberly, R., et al., Init. Repts. DSDP, 32: Washington (U.S. Govt. Printing Office), 925-939.

Schrader, H. J., 1973. Cenozoic diatoms from the northeast Pacific, Leg. 18. In Kulm, L. D., von Huene, R., et al., Init. Repts. DSDP, 18: Washington (U.S. Govt. Printing Office), 673-698.

1974a. Revised diatom stratigraphy of the experimental Mohole drilling, Guadalupe Site. Proc. Cal. Acad. Sci., 39 (No. 23), 517-562.

, 1974b. Cenozoic marine planktonic diatom stratigraphy of the tropical Indian Ocean. In Fisher, R. L., Bunce, E., et al., Init. Repts. DSDP., 24: Washington (U.S. Govt. Printing Office), 887-968.

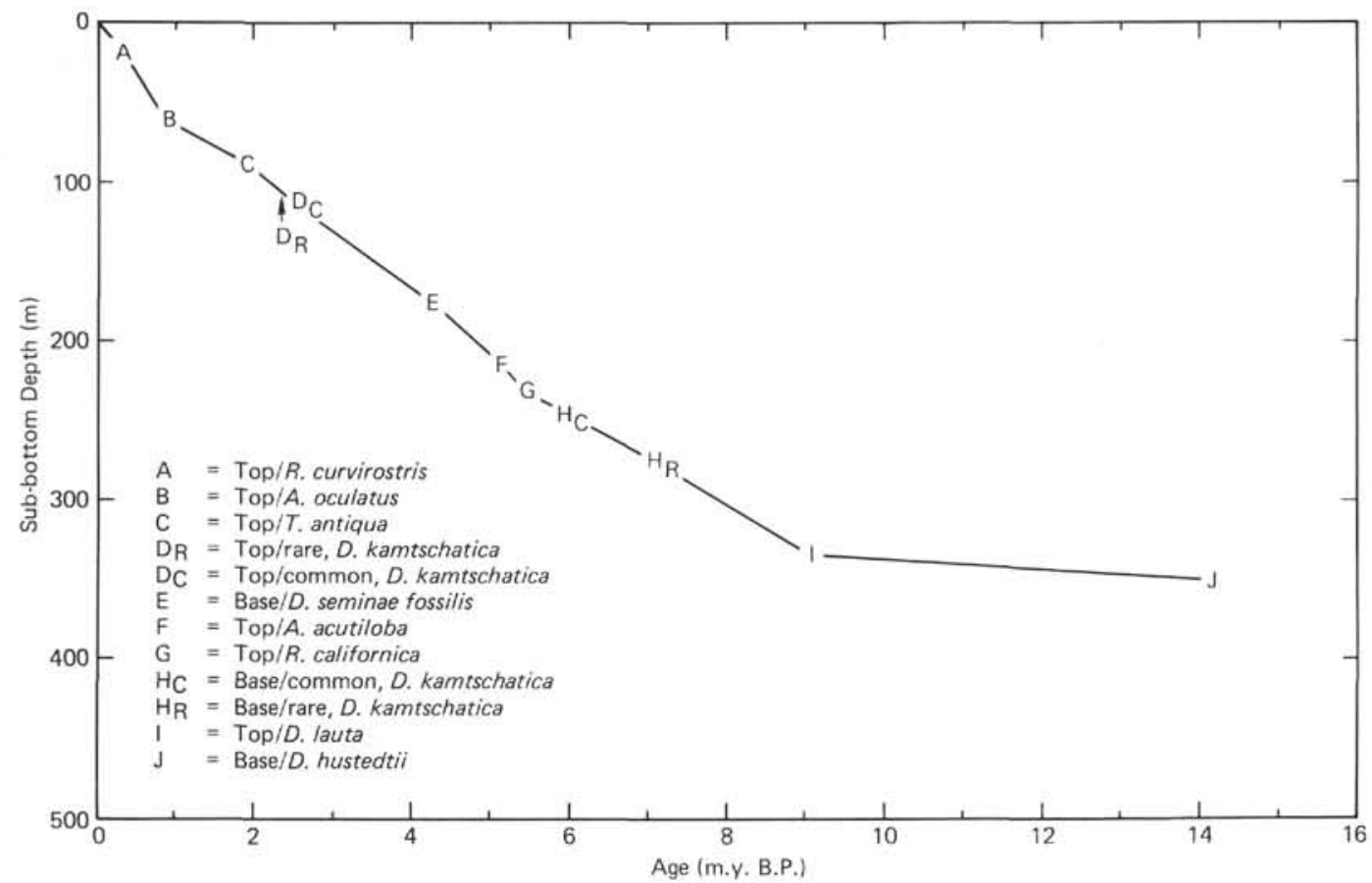

Figure 5. Accumulation rate for Site 436.

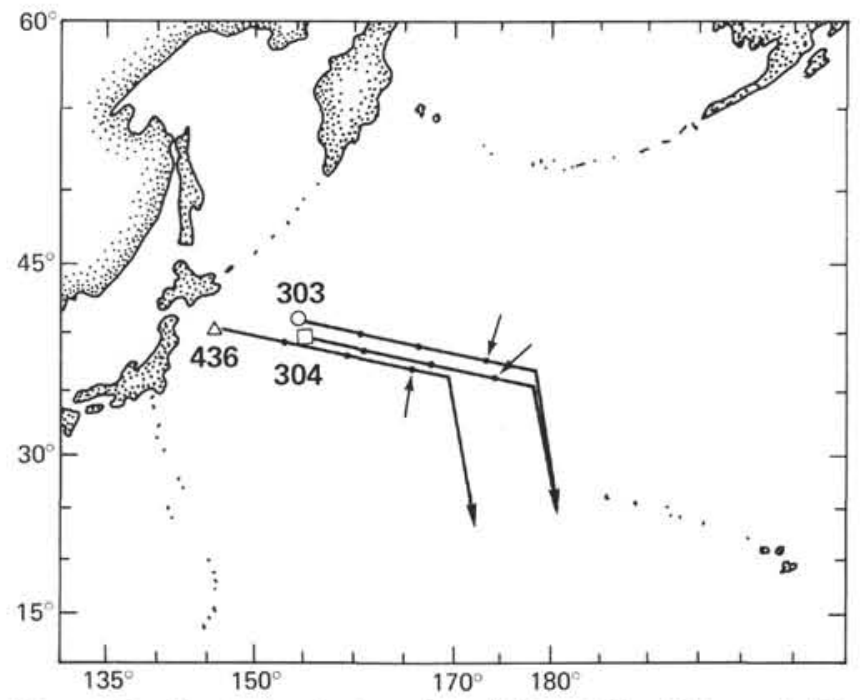

Figure 6. Back-tracked paths of Sites 303, 304, and 436 based on Lancelot and Larson (1975). (Arrows point to position of oldest Tertiary biogenic siliceous sediments.) 